\title{
PENINGKATAN HASIL BELAJAR PESERTA DIDIK MELALUI PENERAPAN MODEL NUMBERED HEAD TOGETHER MENGGUNAKAN MEDIA PUZZLE
}

\author{
Prendi Niki Halhaji ${ }^{1^{*}}$, Irdam Idrus ${ }^{1}$, Sri Irawati ${ }^{1}$ \\ ${ }^{1}$ Program Studi Pendidikan Biologi, Fakultas Keguruan Dan IImu Pendidikan, Universitas Bengkulu \\ E-mail : prendi.nikihalhaji@gmail.com
}

\begin{abstract}
Abstrak
Penelitian ini bertujuan untuk mendeskripsikan peningkatan hasil belajar peserta didik dengan menggunakan model koperatif tipe Numbered Heads Together (NHT) menggunakan media puzzle di Kelas XI IPA ${ }_{1}$ SMA Negeri 2 Bengkulu Selatan. Jenis penelitian ini adalah Penelitian Tindakan Kelas (PTK) dengan metode deskriptif. Penelitian ini terdiri dari dua siklus, masing-masing siklus terdiri dari 4 tahap yaitu tahap perencanaan, pelaksanaan, pengamatan dan refleksi. Subjek penelitian ini adalah guru dan seluruh peserta didik kelas XI IPA ${ }_{1}$ SMA Negeri 2 Bengkulu Selatan. Instrumen penelitian yang digunakan adalah lembar tes dan lembar observasi penilaian hasil belajar ranah psikomotor. Hasil analisis persentase ketuntasan belajar peserta didik ranah kognitif pada siklus I yaitu 59,37\% (tidak tuntas) dan pada siklus II meningkat menjadi $81,25 \%$ (tuntas). Sedangkan dalam ranah psikomotor pada siklus I dengan rerata skor hasil belajar psikomotor peserta didik dari 13,81 mengalami peningkatan di siklus II menjadi 14,86. Dari hasil penelitian dapat disimpulkan bahwa model tipe NHT dapat meningkatkan hasil belajar peserta didik kelas XI IPA ${ }_{1}$ SMA Negeri 2 Bengkulu Selatan.
\end{abstract}

Kata Kunci : Numbered Heads Together (NHT), Hasil Belajar

\begin{abstract}
This research aims to describe an increase in student learning outcomes by using the Numbered Heads Together (NHT) cooperative model by using Puzzle in Class XI IPA $A_{1}$ of South Bengkulu 2 High School. This type of research is Class Action Research with descriptive methods. This study consists of two cycles, each cycle consisting of four stages, namely: the stages of planning, implementation, observation and reflection. The subjects of this research were teachers and all students of Class XI IPA1 of South Bengkulu 2 High School. The instruments of research used were test sheets and observation sheets for assessment of psychomotor domains. The results of the analysis of the percentage of learning completeness of cognitive students in the first cycle were $59.37 \%$ (incomplete) and in the second cycle increased to $81.25 \%$ (complete). Whereas in the psychomotor domain in the first cycle the average score of psychomotor learning outcomes of students from 13.81 increased in the second cycle to 14.86 . From the results of the study it can be concluded that the NHT type model can improve the learning outcomes of students of class XI IPA1 of South Bengkulu 2 High School.
\end{abstract}

Keywords : : Numbered Heads Together (NHT), Learning Outcomes

\section{PENDAHULUAN}

Undang-undang Sistem Pendidikan Nasional Nomor 20 Tahun 2003 pasal 1 ayat (1) menyebutkan bahwa pendidikan adalah usaha sadar dan terencana untuk mewujudkan suasana belajar dalam proses pembelajaran agar peserta didik secara aktif mengembangkan potensi dirinya untuk memiliki kekuatan spiritual keagamaan, pengendalian diri, kecerdasan, akhlak mulia, serta keterampilan yang diperlukan dirinya, masyarakat, bangsa, dan negara. Pendidikan Nasional bertujuan untuk mengembangkan potensi peserta didik agar menjadi manusia yang beriman dan bertaqwa kepada Tuhan Yang Maha Esa, berakhlak mulia, sehat, berilmu, cakap, kreatif, mandiri, dan menjadi warga negara yang demokratis, serta 
bertanggung jawab. Setiap unit atau organisasi yang bergerak dalam bidang pendidikan harus mengacu pada tujuan pendidikan nasional.

Menurut Bloom dalam Jihad dan Haris (2012) terdapat tiga ranah (domain) hasil belajar, yaitu kognitif, afektif, dan psikomotorik. Suprijono (2012) menyatakan bahwa hasil belajar adalah pola-pola perbuatan, nilai-nilai, pengertian-pengertian, sikap-sikap, apresiasi dan ketrampilan. Namun dalam penelitian ini, penilaian hasil belajar dilakukan dalam dua ranah yaitu ranah psikomotorik.

Dalam pelaksanaan pembelajaran masih ditemukan beberapa permasalahan. Sebagaimana berdasarkan wawancara guru Biologi kelas XI MIPA 1 SMAN 2 Bengkulu Selatan tahun ajaran 2018/2019 maka diperoleh masalah seperti 1) Peserta didik kurang berpartisipasi di dalam proses pembelajaran seperti bertanya dan mengemukakan pendapat; dan 2) Peserta didik kurang aktif dan kurang bekerja sama dengan dengan teman kelasnya. Sehingga berdampak pada hasil belajar yang masih rendah. Sebagaimana bahwa data persentase ketuntasan hasil belajar kognitif peserta didik XI IPA1 SMAN 2 Bengkulu Selatan pada mata pelajaran Biologi adalah $65,62 \%$ dari 32 orang peserta didik. Berarti hanya 21 peserta didik dari 32 peserta didik yang telah mencapai Kriteria Ketuntasan Minimal (KKM) yaitu 75 .

\section{Pembelajaran}

dengan menggunakan model kooperatif tipe Numbered Heads Together (NHT) juga merupakan model yang selaras dengan prinsip pembelajaran dalam kurikulum 2013. Sebagaimana menurut Peraturan Mendikbud Nomor 22 Tahun 2016 tentang Standar Proses Pendidikan Dasar dan Menengah bahwa proses pembelajaran pada satuan pendidikan diselenggarakan secara interaktif, inspiratif, menyenangkan, menantang, memotivasi peserta didik untuk berpartisipasi aktif, serta memberikan ruang yang cukup bagi prakarsa, kreativitas, dan kemandirian sesuai dengan bakat, minat, dan perkembangan fisik serta psikologis peserta didik.

$\mathrm{Hal}$ ini sesuai dengan pembelajaran dengan model NHT yang akan menjamin proses pembelajaran untuk lebih interaktif. Sebagaimana menurut Trianto (2011), bahwa model pembelajaran NHT atau penomoran berpikir bersama adalah merupakan jenis pembelajaran kooperatif yang dirancang untuk mempengaruhi pola interaksi peserta didik dan sebagai alternatif terhadap struktur kelas tradisional. Model pembelajaran NHT pertama kali dikembangkan oleh Spencer Kagan pada tahun 1993 untuk melibatkan lebih banyak peserta didik dalam menelaah materi yang tercakup dalam suatu pelajaran dan mengecek pemahaman mereka terhadap isi pelajaran tersebut.

Untuk mendapatkan hasil belajar peserta didik maksimal maka pembelajaran dengan menggunakan model pembelajaran NHT ini akan dikombinasikan dengan media puzzle gambar. Media puzzle adalah sejenis permainan yang berupa potonganpotongan gambar yang cara bermainnya yaitu dengan menyusunnya sehingga terbentuk sebuah gambar, dengan tujuan untuk melatih kesabaran, memudahkan peserta didik dalam memahami konsep, memecahkan masalah, saling bekerja sama dengan teman, serta mengembangkan keterampilan motorik dan kognitif peserta didik. Sehingga dengan adanya penggunaan media puzzle pada model pembelajaran NHT ini akan meningkatkan keterampilan motorik dan kognitif peserta didik yang berdampak 
terhadap pencapaian hasil belajar peserta didik yang maksimal (Husna, dkk. 2017).

Pembelajaran model pembelajaran NHT juga mampu mendorong peserta didik meningkatkan interaksi sosial mereka dalam belajar karena sekumpulan peserta didik merupakan kumpulan dari berbagai individu yang heterogen. Terutama bervariasi dalam tingkat kecerdasan peserta didik tersebut. Sebagaimana menurut Taniredja, dkk (2015) bahwa pada dasarnya pembelajaran kooperatif (Cooperative Learning) mengandung pengertian sebagai suatu sikap atau prilaku bersama dalam bekerja atau membantu di antara sesama dalam struktur kerja sama yang teratur dalam kelompok.

Ada beberapa hasil penelitian relevan yang telah menggunakan model pembelajaran NHT. Adapun diantaranya penelitian oleh Ristiono, dkk (2012), menyatakan bahwa dengan menggunakan model pembelajaran NHT disertai dengan media puzzle dapat meningkatkan hasil belajar peserta didik Kelas XI SMAN 1 Koto XI Tarusan dengan ketuntasan klasikal $69,6 \%$ menjadi $74 \%$. Selanjutnya penelitian oleh Sumarmin, dkk (2017), menyatakan bahwa dengan menggunakan model pembelajaran NHT dapat meningkatkan hasil belajar peserta didik kelas X MIA 2 SMA Negeri 2 Solok Selatan dengan ketuntasan klasikal 64,0\% menjadi $88 \%$.

Berdasarkan latar belakang diatas, maka peneliti dan guru biologi bekerja sama untuk melakukan perbaikan pembelajaran biologi di kelas XI IPA 1 SMA Negeri 2 Bengkulu Selatan dengan menerapkan model pembelajaran NHT disertai dengan media puzzle untuk meningkatkan hasil belajar peserta didik.

\section{METODE}

Jenis penelitian yang digunakan dalam penelitian ini yaitu penelitian tindakan kelas (PTK) yang didasarkan kepada model Kemmis dan Mc Taggart (Sanjaya, 2013). Metode penelitian yang digunakan dalam penelitian ini adalah metode deskriptif (Sugiyono, 2017).

Subyek penelitian ini adalah guru dan peserta didik. Guru dalam penelitian ini adalah peneliti. Sedangkan peserta didik dalam penelitian ini adalah seluruh peserta didik kelas XI IPA 1 SMAN 2 Bengkulu Selatan. Peserta didik berjumlah 32 orang, terdiri dari 11 peserta didik lakilaki dan 21 peserta didik perempuan.

Teknik yang digunakan untuk mengumpulkan data pembelajaran dalam penelitian ini adalah teknik observasi dan tes. Sedangkan instrumen yang digunakan adalah lembar observasi dan lembar tes. Lembar observasi psikomotor peserta didik digunakan untuk mengobservasi penilaian hasil belajar peserta didik ranah psikomotor dalam kegiatan pembelajaran dengan model model pembelajaran NHT. Lembar tes terdiri dari soal-soal pilihan ganda yang digunakan untuk mengukur hasil belajar ranah kognitif peserta didik. Bentuk tes yang digunakan dalam penelitian ini adalah tes objektif yaitu tes yang dalam pemeriksaannya dapat dilakukan secara objektif yang akan diberikan pada akhir pembelajaran.

Menurut Aqib (2014) bahwa untuk menentukan ketuntasan belajar klasikal dari data nilai hasil belajar (kognitif) peserta didik dihitung dengan menggunakan rumus berikut:

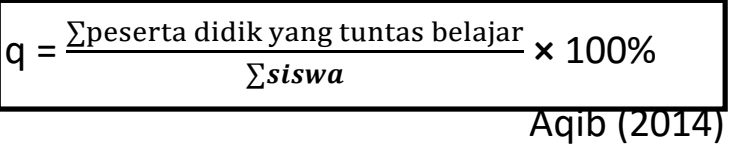

Keterangan :

q = ketuntasan belajar klasikal

¿peserta didik yang tuntas belajar = jumlah peserta didik yang memperoleh nilai $\geq 75$ 
$\sum$ peserta didik $=$ jumlah seluruh peserta didik

Menurut ketentuan yang ditetapkan SMA Negeri 2 Bengkulu Selatan, peserta didik yang dikatakan tuntas belajarnya apabila $\geq 75 \%$ peserta didik telah memperoleh nilai $\geq 75$.

Adapun teknik analisis data dalam penelitian ini menurut Arikunto (2012) dalam menganalisis data observasi dilakukan dengan cara berikut ;

Rata-rata skor $=\frac{\text { jumlah skor }}{\text { jumlah pengamat }}$

Arikunto (2012)

Skor tertinggi $=$ Jumlah aspek yang diamati $x$ Skor tertinggi tiap aspek

Skor terendah = Jumlah aspek yang diamati $x$ Skor terendah tiap aspek

Selisih skor= Skor Tertinggi- Skor Terendah

Kisaran nilai tiap kriteria $=$

$$
\frac{\text { selisih skor }}{\text { jumlah kriteria penilaian }}
$$

Arikunto (2012)

Lembar observasi psikomotor peserta didik berjumlah 6 butir pengamatan, skor tertinggi tiap butir 3 dan skor terendah tiap butir 1, maka kategori penilaian untuk lembar observasi psikomotor peserta didik dapat dilihat pada Tabel 1 :

Tabel 1 : Kisaran Nilai Lembar Observasi Psikomotor Peserta Didik

\begin{tabular}{cc}
\hline Rentang Skor & Kategori Penilaian \\
\hline $6-9$ & Kurang \\
$10-13$ & Cukup \\
$14-18$ & Baik \\
\hline
\end{tabular}

\section{HASIL DAN PEMBAHASAN}

Adapun hasil dari pelaksanan post test hasil belajar ranah kognitif peserta didik pada siklus I dan II menghasilkan beberapa data sesuai dengan Gambar 1 :

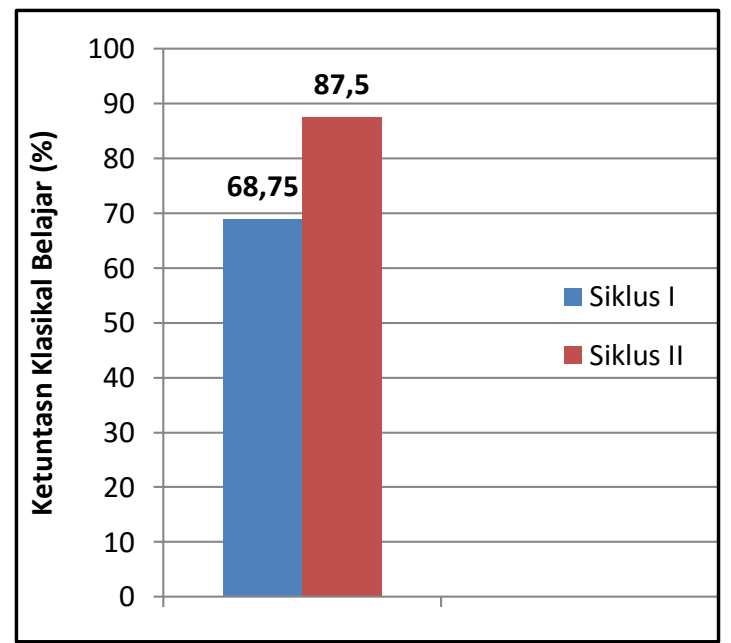

Gambar 1. Diagram Persentase Ketuntasan Klasikal Hasil Belajar Peserta Didik Ranah Kognitif Siklus I dan II

Berdasarkan Gambar 1 tersebut, diketahui bahwa hasil belajar peserta didik ranah kognitif pada siklus I yaitu $68,75 \%$ (belum tuntas), meningkat menjadi 87,5 \% (tuntas) pada siklus II. Kemudian hasil dari pelaksanan observasi hasil belajar ranah psikomotor peserta didik pada siklus I dan II dapat dilihat pada Gambar 2 :

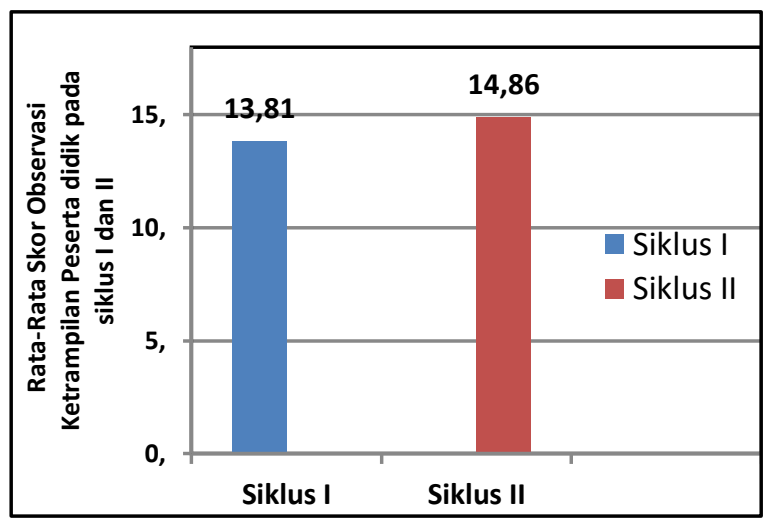

Gambar 2. Diagram Rata-Rata Skor Observasi Psikomotor Peserta Didik pada Siklus I dan II

Diketahui bahwa hasil belajar peserta didik ranah psikomotor pada siklus I dengan rerata skor dari 13,81 mengalami peningkatan di siklus II menjadi 14,86 . Adapun angka ini rata-rata skor observasi penilaian psikomotor 
berdasarkan kategori penilaian psikomotor sesuai dengan perhitungan analisis data observasi. Berdasarkan dari perhitungan pada perhitungan di lembar observasi ada tahap kegiatan inti pembelajaran, terdapat beberapa aktivitas guru dan aktivitas peserta didik dalam setiap sintaks pembelajaran dengan model pembelajaran NHT sebagai berikut :

1) Penomoran (Numbering)

Pada sintaks ini, guru membimbing peserta didik dalam pembagian kelompok secara heterogen dan memberikan kartu nomor dengan baik. Lalu peserta didik juga merespon dengan baik dengan membentuk kelompok dan duduk pada masing-masing kelompoknya. Hal ini sesuai dengan Trianto (2011), bahwa dalam sintaks penomoran pada model pembelajaran NHT guru membagi peserta didik ke dalam beberapa kelompok dan kepada setiap anggota kelompok diberi kartu nomor tertentu.

Guru membagi siswa ke dalam kelompok heterogen yang terdiri 3-5 orang peserta didik dengan menggunakan cara undian. Peserta didik mengambil setiap kertas undian yang diberikan oleh guru. Kemudian, peserta didik membuka kertas tersebut yang berisikan nomor kelompok masing-masing. Sehingga setiap peserta didik yang memiliki nomor yang sama merupakan satu kelompok. Setelah dilakukan undian, maka guru mengintruksikan kepada peserta didik untuk berkumpul ke kelompoknya masing-masing. Hasil pembentukan kelompok diskusi menghasilkan kelompok sebanyak 5 kelompok.

2) Pengajuan Pertanyaan (Submitting questions)

Pada aspek kedua, yaitu guru menjelaskan prosedur LDPD (Lembar Diskusi Peserta Didik) kepada seluruh peserta didik. Pada siklus I, aktivitas guru pada aspek ini dinilai cukup oleh kedua pengamat karena guru hanya menjelaskan prosedur sesuai dengan LDPD (Lembar Diskusi Peserta Didik) namun tidak sistematis. Selanjutnya dilakukan refleksi dan perbaikan dilakukan di siklus II, sehingga aktivitas guru dan aktivitas peserta didik terjadi peningkatan dan mendapat kriteria penilaian baik oleh kedua pengamat. Hal ini dikarenakan guru telah menjelaskan prosedur sesuai dengan LDPD (Lembar Diskusi Peserta Didik) secara sistematis.

Pada sintaks ini, dilakukan penggunaan media puzzle sebagai media pembelajaran yang membantu proses pembelajaran yang diintegrasikan bersama LDPD (Lembar Diskusi Peserta Didik). Lalu guru menjelaskan prosedur pengerjaan LDPD (Lembar Diskusi Peserta Didik) dan memberikan media puzzle tersebut kepada masing-masing kelompok, dan meminta kepada peserta didik untuk menyusun media puzzle menjadi sebuah gambar organ indra secara utuh beserta bagian-bagiannya yang hanya diberi petunjuk tanda panah dan kode nomor. Sehingga peserta didik diminta memberikan keterangan lengkap pada setiap bagian organ panca indra tersebut ke dalam LDPD.

Pada aktivitas peserta didik di siklus I, bahwa seluruh kelompok peserta didik menjawab pertanyaan sesuai yang ada di LDPD mengenai struktur dan fungsi sistem indra, sedangkan di siklus II mengenai mekanisme dan kelainan pada sistem indra

Penggunaan media ini berperan dalam meningkatkan aktivitas peserta didik dalam berdiskusi berkelompok serta membantu peserta didik dalam memahami konsep melalui gambar. Hal ini sesuai menurut Ristiono, dkk (2012) bahwa media puzzle jika disusun secara berkelompok maka dapat memungkinkan interaksi sosial peserta didik. Dalam kelompok, peserta didik akan saling 
menghargai, saling membantu dan berkegiatan untuk menyelesaikan masalah.

\section{3) Berpikir Bersama (Discussing)}

Pada sintaks ini, aktivitas guru berupa mendorong peserta didik dalam kelompok untuk mengumpulkan informasi yang sesuai dengan beberapa pertanyaan yang terdapat pada LDPD (Lembar Diskusi Peserta Didik), kemudian peserta didik membahas hasil diskusi terkait materi sistem indra. Kemudian guru mendatangi setiap kelompok peserta didik untuk membimbing kelompok mendiskusikan mengenai materi sistem indra sesuai dengan beberapa pertanyaan diskusi yang telah tertera pada LDPD (Lembar Diskusi Peserta Didik). Hal ini sesuai menurut Suparmi (2015) bahwa penggunaan model pembelajaran ini dapat melibatkan peserta didik untuk dapat berpikir sehingga mereka dapat terlibat langsung dalam proses pembelajaran.

Pada siklus I, diamati bahwa hanya sebagian peserta didik (3-4 siswa) dalam suatu kelompok berdiskusi untuk menjawab beberapa soal diskusi yang disediakan pada LDPD (Lembar Diskusi Peserta Didik). Sedangkan pada siklus II, diamati bahwa seluruh anggota kelompok belum berdiskusi secara utuh untuk menjawab beberapa soal diskusi yang disediakan pada LDPD. Sehingga masih terdapat beberapa peserta didik dalam suatu kelompok yang cenderung pasif untuk berdiskusi secara bersama. Sebaiknya seluruh peserta didik berdiskusi secara utuh untuk menjawab beberapa soal di LDPD.

Pada sintaks berpikir bersama ini terdapat kegiatan diskusi di dalam pembelajarannya. Kegiatan diskusi ini memiliki beberapa kelebihan yaitu mampu memberikan dorongan kepada setiap anggota kelompok untuk berbuat secara konstruktif, berpikir kreatif terhadap suatu subjek, dan menyumbangkan pengalaman dan keahliannya yang berguna untuk kepentingan bersama-sama. Sehingga mampu meningkatkan pengembangan konsep bagi peserta didik yang dibangun dalam pikiran peserta didik, dan keterampilan peserta didik yang diperolehnya dari proses pengetahuan dan pengalamannya (Side, dkk. 2013).

Maka dengan adanya kegiatan diskusi dalam sintaks model pembelajaran ini akan mendukung terhadap peningkatakan hasil belajar peserta didik. Hal ini didukung oleh penelitian yang dilakukan oleh Herviza,dkk (2018), yang menyatakan bahwa salah satu faktor peningkatan hasil belajar peserta didik pada proses pembelajaran adalah kegiatan diskusi dan saling bekerja sama antar peserta didik.

4) Pemberian Jawaban (Answering) Pada sintaks ini, guru membimbing peserta didik secara individual untuk aktif ikut mempresentasikan jawaban hasil diskusi sedangkan aktivitas peserta didik yaitu secara individual aktif untuk mempresentasikan jawaban hasil diskusi dari beberapa pertanyaan pada lembar diskusi. Pada sintaks ini, aktivitas guru adalah memanggil suatu nomor tertentu untuk meminta peserta didik menjawab pertanyaan pada LDPD (Lembar Diskusi Peserta Didik).

Pada sintaks ini, keaktifan peserta didik sangat dituntut karena setiap kelompok harus mempresentasikan masing-masing dari hasil diskusi secara maksimal sehingga mampu berperan baik bagi kelompoknya. Berdasarkan pengamatan aktivitas peserta didik sudah baik pada siklus I dan siklus II, karena seluruh peserta didik yang nomornya disebutkan oleh guru bisa memberikan pendapat ataupun jawaban terkait pertanyaaan pada LDPD (Lembar Diskusi Peserta Didik) dengan baik. 


\begin{abstract}
Dapat diketahui bahwa hasil belajar ranah kognitif peserta didik mengalami peningkatan dengan menggunakan model pembelajaran koperatif NHT pada pembelajaran biologi materi sistem indra pada manusia. Hasil belajar kognitif peserta didik pada siklus I, jumlah peserta didik yang mencapai ketuntasan belajar klasikal sebanyak 22 orang dan jumlah peserta didik belum tuntas sebanyak 10 orang dengan persentase ketuntasan belajar klasikal peserta didik $68,75 \%$ dinyatakan belum tuntas. Sedangkan hasil belajar kognitif peserta didik pada siklus II jumlah peserta didik yang mencapai ketuntasan belajar klasikal sebanyak 28 orang dan jumlah peserta didik belum tuntas sebanyak 4 orang dengan persentase ketuntasan belajar klasikal peserta didik 87,5\% dinyatakan tuntas. Berdasarkan ketetapan SMA Negeri 2 Bengkulu Selatan yang menyatakan bahwa hasil belajar peserta didik dapat dinyatakan tuntas secara klasikal apabila mencapai $\geq 75 \%$.
\end{abstract}

Dari hasil penelitian penggunaan model pembelajaran NHT ini, diketahui bahwa model ini dapat meningkatkan hasil belajar kognitif peserta didik. Hal ini didukung oleh penelitian yang dilakukan oleh Ristiono,dkk (2012), menyatakan bahwa dengan menggunakan model pembelajaran NHT disertai dengan media puzzle dapat meningkatkan hasil belajar peserta didik Kelas XI SMAN 1 Koto XI Tarusan dengan ketuntasan klasikal 69,6 $\%$ menjadi $74 \%$.

Berdasarkan hasil penelitian, peningkatan juga terjadi pada hasil belajar peserta didik ranah psikomotor. Adapun data observasi hasil belajar ranah psikomotor peserta didik pada siklus I diketahui bahwa rerata skor observasi untuk seluruh peserta didik adalah 13,81 yang termasuk dalam kriteria Cukup (B). Sedangkan pada siklus II data observasi hasil belajar ranah psikomotor peserta didik diketahui bahwa rerata skor observasi untuk seluruh peserta didik adalah 14,86 yang termasuk dalam kriteria baik (A). Berdasarkan data tersebut, dapat diketahui bahwa penerapan model pembelajaran kooperatif NHT dalam 2 siklus pada materi sistem indra dapat meningkatkan hasil belajar ranah psikomotor pada peserta didik. Hal ini dilihat dari peningkatan ratarata skor hasil observasi keterampilan psikomotor peserta didik pada siklus I dan siklus II.

Peningkatan juga terjadi dari persentase pencapaian peserta didik dengan kriteria baik pada hasil belajar ranah psikomotor dari siklus I dan II. Berdasarkan hasil penelitian bahwa pada siklus I diketahui bahwa persentase peserta didik dengan kriteria baik pada hasil belajar ranah psikomotor yaitu 59,37\%. Sedangkan pada siklus II diketahui bahwa persentase peserta didik dengan kriteria baik pada hasil belajar ranah psikomotor yaitu $81,25 \%$.

Dari hasil penelitian penggunaan model pembelajaran NHT ini, diketahui bahwa model ini dapat meningkatkan hasil belajar psikomotor peserta didik. Hal ini didukung oleh penelitian yang dilakukan oleh Sumarmin, dkk (2017), menyatakan bahwa dengan menggunakan model pembelajaran NHT dapat meningkatkan hasil belajar peserta didik dalam ranah psikomotor kelas X MIA 2 SMA Negeri 2 Solok Selatan.

Jadi dapat disimpulkan bahwa penerapan model pembelajaran kooperatif NHT dapat meningkatkan hasil belajar peserta didik ranah kognitif dan ranah psikomotor. Peningkatan hasil belajar ini dikarenakan guru memberikan kesempatan kepada peserta didik untuk lebih aktif dalam proses pembelajaran. 


\section{PENUTUP}

\section{Simpulan}

Adapun kesimpulan dalam penelitian tindakan kelas ini adalah sebagai berikut :

Pembelajaran biologi pada materi sistem indra dengan menerapkan model koperatif NHT dapat meningkatkan hasil belajar peserta didik kelas XI IPA ${ }_{1}$ SMA Negeri 2 Bengkulu Selatan pada ranah kognitif dengan ketuntasan belajar klasikal dari 59,37 \% menjadi 81,25\% dan dalam ranah psikomotor pada siklus I dengan rerata skor psikomotor peserta didik dari 13,81 mengalami peningkatan di siklus II menjadi 14,86 .

\section{Saran}

1) Untuk penelitian selanjutnya, diharapkan dapat mengoptimalkan lagi tiap sintaks pada model Numbered Heads Together (NHT) terutama pada sintaks berpikir bersama, karena pada aktivitas guru diupayakan agar guru membimbing seluruh kelompok dengan maksimal agar tercapainya proses belajar yang baik.

2) Untuk penelitian selanjutnya diharapkan peneliti lebih mengoptimalkan tiap sintaks model Numbered Heads Together (NHT) dan dapat mengatur durasi pembelajaran dengan sebaik mungkin agar mendapatkan proses pembelajaran yang baik.

\section{DAFTAR PUSTAKA}

Aqib, Zainal. 2014. Model-Model, Media, dan Strategi Pembelajaran Kontekstual (Inovatif). Bandung : Yrama Widya.

Arikunto, Suharsimi. (2012). Prosedur Penelitian Suatu Pendekatan Praktek. Jakarta: Rineka Cipta.

Herviza, Meftha,. Jumiarni, Dewi,. dan Irawati, Sri. 2018. Peningkatan Hasil Belajar Melalui Model Kooperatif Tipe
Jigsaw pada Peserta Didik Smpn 3 Kaur. Jurnal Pendidikan dan Pembelajaran Biologi. Vol 2(2): 94101.

Husna, Nurul,. Sar, Sri Adelila ,. dan A, Halim. 2017. Pengembangan Media Puzzle Materi Pencemaran Lingkungan di SMP Negeri 4 Banda Aceh. Jurnal Pendidikan Sains Indonesia. Vol 5 (1) : 66.

Jihad, Asep dan Haris, Abdul. 2012. Evaluasi Pembelajaran. Yogyakarta : Multi Pressindo.

Peraturan Mendikbud Nomor 22 Tahun 2016. Tentang Standar Proses Pendidikan Dasar dan Menengah. Jakarta: Kementerian Pendidikan Dan Kebudayaan Republik Indonesia (Salinan).

Ristiono,.Novriyanti, Ernie,. dan Yuda, Lamia Trisni. 2012. Pengaruh Penggunaan Media Puzzle Gambar Berwarna Dalam Pembelajaran Kooperatif Tipe NHT Terhadap Hasil Belajar Biologi Peserta didik Kelas XI SMAN 1 Koto XI Tarusan. Jurnal Ta'dib. Volume 15 (1):107.

Sanjaya, Wina. 2013. Penelitian Tindakan Kelas Jakarta : Pranamedia Grup.

Side, Sumiati,. Hardin,. dan Tanrere, Munir. 2013. Penerapan Metode Diskusi Berkelanjutan pada Mata Pelajaran Kimia untuk Meningkatkan Keaktifan dan Hasil Belajar Peserta didik Kelas XI IPA 6 SMA Negeri 11 Makassar. Jurnal Chemica. Vol 14 (1) : 46.

Sugiyono. 2017. Statistika Untuk Penelitian. Bandung : Alfabeta.

Sumarmin, Ramadhan,. Pardismi,. dan Gusril. 2017. Penerapan Model Pembelajaran Kooperatif Tipe Numbered Heads Together untuk Meningkatkan Kompetensi Belajar 
Biologi Siswa Kelas X MIA2 SMA Negeri 2 Solok Selatan. Bioeducation Journal. Vol I (2) : 47.

Suparmi. 2015. Penggunaan Model Pembelajaran Kooperatif Tipe Numbered Heads Together (NHT) Untuk Meningkatkan Aktivitas Dan Hasil Belajar Biologi Kelas VII-1 SMPN 25 Pekanbaru. Jurnal Program Studi Pendidikan Guru Sekolah Dasar Fakultas Keguruan dan IImu Pendidikan Universitas Riau. Volume 4 (2) : 99.

Suprijono, Agus. 2012. Cooperative Learning Teori dan Aplikasi PAIKEM. Yogyakarta : Pustaka Pelajar.

Taniredja, Tukiran,. Faridli, Efi Miftah,. dan Harmianto, Sri. 2015. Model-Model Pembelajaran Inovatif dan Efektif. Bandung : Alfabeta.

Trianto. 2011. Model Pembelajaran Terpadu. Jakarta : PT Bumi Aksara.

Undang-undang Nomor 20 Tahun 2003. Tentang Sistem Pendidikan Nasional. Jakarta : Bidang Dikbud KBRI Tokyo. 